\title{
Tomasz Szwaciński
}

Warszawa

\section{Tumult wileński 1755 roku i jego reperkusje}

\begin{abstract}
Zarys treści
Pod koniec sierpnia 1755 r. w czasie sesji trybunału w Wilnie doszło do krwawych zajść. Był to element zaostrzającej się wówczas walki stronnictw na Litwie. Obie strony konfliktu - obozy wokół Radziwiłłów i Czartoryskich - oskarżały się wzajemnie o bezprawie i wysłały odpowiednie „diariusze” na dwór królewski do Drezna, a Michał Czartoryski poprosił Rosję o pomoc przed reasumpcją trybunału litewskiego w $1756 \mathrm{r}$.
\end{abstract}

\begin{abstract}
At the end of August 1755 at the tribunal in Wilno (Vilna, Vilnius) there was a bloody incident. It was a symptom of intensifying rivalry between the factions in Lithuania. Both sides - the camps around the Radziwiłł and the Czartoryski families - accused each other of lawlessness and sent the relevant 'diaries' to the royal court in Dresden, and Michał Czartoryski asked Russia for help before the resumption of the Lithuanian tribunal in 1756.
\end{abstract}

Słowa kluczowe: trybunał, Litwa, Rzeczpospolita, Rosja, kanclerz, hetman, rywalizacja stronnictw Keywords: tribunal, Lithuania, Commonwealth, Russia, chancellor, hetman, factions' rivalry

Po zakończeniu kadencji wileńskiej Trybunału Głównego Wielkiego Księstwa Litewskiego w 1755 r. doszło do gwałtownego tumultu, którego reperkusje w ciągu następnych kilku miesięcy stanowiły ważny element ówczesnej politycznej rywalizacji stronnictw. Wydarzenie to stało się również istotnym elementem starań Michała Czartoryskiego u uzyskanie protekcji rosyjskiej przed kolejną reasumpcją. Tymczasem do tej pory o tytułowym zagadnieniu wspominali wyłącznie incydentalnie Andrej Macuk ${ }^{1}$ i niżej podpisany ${ }^{2}$.

Odtworzenie wydarzeń związanych z tumultem wileńskim było możliwe dzięki korespondencji Michała Kazimierza Radziwiłła z agentem hetmańskim w Dreźnie, Andrzejem Protasowiczem, oraz kopiariuszowi listów wychodzących od hetmana

\footnotetext{
${ }^{1}$ А. Мацук, Барацьба магнацкіх груповак у ВКЛ (1717-1763 гг.), Мінск 2010.

${ }^{2}$ T. Szwaciński, Protekcja rosyjska udzielana przedstawicielom szlachty litewskiej u progu wojny siedmioletniej. Postawienie problemu, „Kwartalnik Historyczny” 2011, t. 118, nr 1, s. 47-83.
} 
wielkiego litewskiego, które znajdują się w zbiorach Archiwum Radziwiłłów w Archiwum Głównym Akt Dawnych w Warszawie. Ponadto - dzięki listom Michała Antoniego Sapiehy do Michała Czartoryskiego, zachowanym w Bibliotece Narodowej w Warszawie, a także rosyjskiej korespondencji dyplomatycznej w Archiwum Polityki Zagranicznej Imperium Rosyjskiego w Moskwie. Ze źródeł drukowanych pomocny okazał się Diariusz życia mego Marcina Matuszewicza ${ }^{3}$.

Głównymi uczestnikami tytułowego zajścia byli „partyzanci” średniego szczebla zwalczających się dwóch obozów. Ze strony Familii, jej działacz w powiecie pińskim, tamtejszy podstarości grodzki Piotr Tadeusz Frąckiewicz. Wedle Matuszewicza ten „zawołany w szalbierstwie, addictus księciu kanclerzowi lit.” miał, przekupiwszy posła starodubowskiego Michała Strawińskiego, być bezpośrednim wykonawcą zerwania sejmu 1754 r. Natomiast na trybunale 1755 r. był plenipotentem Michała Czartoryskiego ${ }^{4}$. Pamiętnikarz dwa razy powtórzył informację, jakoby Frąckiewicz, jeszcze przed tumultem wileńskim, jeździł do Rygi, skąd przywiózł Michałowi Czartoryskiemu 6000 czerw. zł rosyjskiego wsparcia na proces $\mathrm{z}$ Matuszewiczami ${ }^{5}$. Potwierdzenie wiarygodności tego przekazu wymaga jednak dalszych badań. Natomiast ze strony partii radziwiłłowskiej, jej „partyzant” z Mińska, starosta krasowski i deputat miński Józef Wołodkowicz wydelegowany wcześniej przez trybunał do powitania Augusta III we Wschowie w maju $1755 \mathrm{r}^{7}$

Po zerwanym sejmie warszawskim (tzw. sejmie ostrogskim) w listopadzie 1754 r. doszło do ostrej (choć krótkotrwałej) polaryzacji sceny politycznej Rzeczypospolitej. Z jednej strony stanął obóz dworsko-hetmański („koalicja antykolbuszowska”), z drugiej (znacznie słabsza) „familia” z sojusznikami („partia kolbuszowska"). Dzięki rychłemu konfliktowi hetmana wielkiego koronnego Jana Klemensa Branickiego z dworem królewskim, a także udzielonej „familii” protekcji rosyjskiej i brytyjskiej, która zaowocowała ograniczonym dostępem tego stronnictwa do nadań, po wschowskiej radzie senatu w maju 1755 r. sytuacja na krajowej scenie politycznej uzyskała względną równowagę; nastąpiło odprężenie ${ }^{8}$.

W warunkach litewskich układ sił po sejmie warszawskim oznaczał zaostrzenie konfliktu między sojuszniczym wobec Drezna Nieświeżem (hetman wielki litewski

\footnotetext{
${ }^{3}$ M. Matuszewicz, Diariusz życia mego, wyd. B. Królikowski, koment. Z. Zielińska, Warszawa 1986, t. 1: $1714-1757 ;$ t. $2: 1758-1764$.

${ }^{4}$ Ibidem, t. 1, s. 441, 557-558.

${ }^{5}$ Ibidem, s. 557, 640.

${ }^{6}$ Deputaci Trybunału Głównego Wielkiego Księstwa Litewskiego (1697-1794). Spis, oprac. A. Rachuba, P.P. Romaniuk, współpr. A. Macuk, J. Aniszczanko, Warszawa 2004, s. 245.

${ }^{7}$ M.K. Radziwiłł do A. Protasowicza, Mir, 7 IX 1755, AGAD, AR, dz. IV, nr 876 [dalej: AR IV 876], s. 1054.

${ }^{8}$ W. Konopczyński, Polska $w$ dobie wojny siedmioletniej, cz. 1: 1755-1758, Kraków-Warszawa 1909, s. 1-55; T. Szwaciński, Finat sejmu 1754 r. w relacjach rosyjskich i brytyjskich, „Biblioteka Epoki Nowożytnej" 2016, t. 4, s. 163-195.
} 
Michał Kazimierz Radziwiłł) a opozycyjnym Wołczynem (kanclerz litewski Michał Czartoryski) ${ }^{9}$.

Dysponując wsparciem dworu królewskiego, Radziwiłłowie przeszli do politycznej ofensywy. 14 kwietnia 1755 r. marszałkiem trybunału został syn hetmana, miecznik litewski Karol Stanisław Radziwiłł, a inne funkcje przypadły jego politycznym sojusznikom. „Słowem wszystko się stało według woli i myśli książąt Radziwiłłów"10. Tylko wybór marszałka trybunału skarbowego został odłożony do początku prac tego organu ${ }^{11}$. W Nieświeżu projektowano trwałe podważenie wpływów „familii” w Wielkim Księstwie, czego wyrazem były plany, aby - w porozumieniu z przywódcą dworskiej „kamaryli”, Jerzym Augustem Mniszchem - opanować także reasumpcję w kolejnym roku, a marszałkiem trybunalskim uczynić strażnika litewskiego Ludwika Pocieja ${ }^{12}$.

W Wołczynie bardzo szybko zaczęto planować kontrakcję. Już w dniu reasumpcji (nie mając jeszcze informacji z Wilna) kanclerz Czartoryski stwierdził: „Do sejmików zaś gromnicznych in posterum trzeba będzie dostateczniejszych mensur i żywszych starań, niżeli były w teraźniejszym roku na wielu miejscach"13. Niepomyślna dla Radziwiłłów obsada województwa nowogródzkiego we Wschowie (maj 1755), mogła dawać nadzieję, że - wzorem Korony - nastąpi kryzys w relacjach hetmana wielkiego $\mathrm{z}$ dworem ${ }^{14}$. Zapewne rychło $\mathrm{w}$ Wołczynie i Puławach podjęto decyzję, że terenem kolejnej próby sił stronnictw będzie reasumpcja trybunału litewskiego w 1756 r. Aby zapewnić sobie sukces, należało skompromitować trybunał pod laską Radziwiłła, przedstawić się w roli ofiary niesłychanego gwałtu i tą drogą skłonić dwór petersburski do ponowienia protekcji. Pierwszej okazji po temu nastarczyły wydarzenia w Wilnie, które rozegrały się na przełomie sierpnia i września $1755 \mathrm{r}$.

Wedle Diariusza Marcina Matuszewicza, początek trybunału skarbowego w Wilnie przyniósł gwałtowny spór o obsadę marszałkowstwa tego gremium. Biskup wileński Michał Zienkowicz (stronnik „familii”) promował swojego siostrzeńca Andrzeja Zienkowicza, pisarza skarbowego litewskiego i deputata

\footnotetext{
${ }^{9}$ Na temat relacji M.K. Radziwiłła z J.A. Mniszchem zob. M. Czeppe, Kamaryla Pana z Dukli. Kształtowanie się obozu politycznego Jerzego Augusta Mniszcha 1750-1763, Warszawa 1998 , s. 106-112. Na temat sytuacji politycznej na Litwie w 1754 r. (stopniowe słabnięcie „familii”) zob. А. Мацук, Унутрыпалітычная сітуацыя у Вялікім Княстве Літоускім у сярэдзіне XVIII cm. у сувязі з падзелам Астрожскай ардынацы і, „АRСНЕ-Пачатак” 2011, nr 6 (105), s. 115-141.

${ }_{10}$ M. Matuszewicz, op. cit., t. 1, s. 508-512; Deputaci..., s. 242; А. Мацук, Барацьба..., s. 386-396.

${ }^{11}$ M. Matuszewicz, op. cit., t. 1, s. 510.

${ }^{12}$ Instrukcja M.K. Radziwiłła dla M. Matuszewicza do Wschowy, Niemieża, 26 IV 1755, w: M. Matuszewicz, op. cit., t. 1, s. 517; Z. Zielińska, Pociej Ludwik, w: PSB, t. 27, Wrocław 1983 , s. 47; А. Мацук, Барацьба..., s. 396.

${ }^{13}$ M. Czartoryski do A. Przeździeckiego, Wołczyn, 14 IV 1755, B. Czartoryskich, rkps 3127, s. 71; por. А. Мацук, Барацьба..., s. 399 (błąd w datacji).

${ }^{14}$ T. Szwaciński, Protekcja rosyjska..., s. 54.
} 
słonimskiego, natomiast Karol Stanisław Radziwiłł obstawał przy kandydaturze Franciszka Weryhy Darewskiego, starosty pokorszańskiego, deputata oszmiańskiego i podskarbiego trybunalskiego. Spodziewane zwycięstwo kandydatury radziwiłłowskiej skłoniło jakoby stronników kanclerza do zastosowania przemocy. Frąckiewicz zorganizował w pałacu Flemminga dla sojuszników „familii” „wieczorną pijatykę", na którą zaprosił przejeżdżającego obok Wołodkowicza. Stronnik Nieświeża przypłacił swą wizytę brutalną napaścią, której celem było wyeliminowanie go $\mathrm{z}$ głosowania i rzucenie postrachu na innych. Wśród napastników znajdowali się także deputaci Stanisław Zawisza, Felicjan Daneyko oraz Kazimierz Hołyński. Gdy nadciągać zaczęła odsiecz pod wodzą miecznika litewskiego, napastnicy rozpierzchli się, a Frąckiewicz skrył się między trumnami w podziemiach kościoła franciszkanów. Nazajutrz sprawa wywołała ogromne poruszenie, a na Frąckiewicza i trzech wspomnianych deputatów został zaniesiony solenny manifest. Trzy dni później w obecności Wołodkowicza przywołano aktorat, lecz oskarżeni się nie stawili. Wydano zatem kondemnatę, „a osobliwie na Frąckiewicza na łapanie i gardło. Pokryli się deputaci po klasztorach, a Frąckiewicz po niejakim czasie uciekł od franciszkanów i przebrał się do Wołczyna”. Laska skarbowa jednogłośnie dostała się kandydatowi radziwiłłowskiemu ${ }^{15}$.

Swoją wersję wydarzeń „familia” zawarła w specjalnym diariuszu, który zaopatrzony został w stosowny komentarz. Pismo to obok Frąckiewicza za osądzonych przez przeciwników uznawało podstarościego mścisławskiego i chorążego husarskiego Józefa Antoniego Hołyńskiego oraz horodniczego witebskiego Marcina Hurkę ${ }^{16}$.

Dowiedziawszy się o zajściach, hetman Radziwiłł w liście do wojewodziny nowogródzkiej przewidywał zarzuty wobec marszałka trybunalskiego, „że dekret po waledykcyi trybunału ferował", ale podkreślał, że stało się to zanim skład sędziowski się rozszedł, a trybunał skarbowy został rozpoczęty. Sytuacja była też nadzwyczajna „ile niesłychana prawie od wieków praktyka, aby zgwałceniem tylu praw, prerogatywę sędziowską ubezpieczających, był kiedy deputat zrąbany". „Rybeńko” wysłał także do Zdzięcioła tekst z radziwiłłowską wersją wydarzeń ${ }^{17}$.

${ }^{15}$ M. Matuszewicz, op. cit., t. 1, s. 567-568. Deputat mścisławski K. Hołyński był rotmistrzem, a więc pełnił służbę wojskową, co w przyszłości będzie miało pewne znaczenie.

${ }^{16}$ Ekstrakt diariusza wileńskiego 29 VIII - 2 IX 1755 (z prawej diariusz, z lewej „observanda”), APZIR, f. 79/1, d. 1755/7, k. 367-370v. Ze względu na ograniczenia czasowe podczas kwerendy w Moskwie nie udało mi się dostatecznie wykorzystać tego źródła. Imiona i szarże wojskowe Hołyńskiego i Hurki udało się ustalić dzięki uprzejmości pp. Przemysława P. Romaniuka i dr. Andreja Macuka, którym składam szczere podziękowania.

${ }^{17}$ M.K. Radziwiłł do B. Radziwiłłowej, Korelicze, 5 IX 1755, AR IV 876, s. 1051. Niestety nie znamy tekstu wspomnianej relacji, jej tekst został wysłany także do komisarza poczt koronnych A. Gibesa (M.K. Radziwiłł do A. Gibesa, Mir, 7 IX 1755, ibidem, s. 1057) oraz do Drezna i J.K. Branickiego, o czym niżej. 
Rany Wołodkowicza musiały być rzeczywiście bardzo poważne, skoro w ciągu następnych dni poważnie obawiano się o jego życie ${ }^{18}$.

Zgodnie z relacją zdaną dwa tygodnie później przez Ignacego Massalskiego bratu Józefowi, trybunał skarbowy zakończył się potwierdzeniem wcześniejszego wyroku skazującego Frąckiewicza, natomiast Hołyńskiemu i Hurce pozwolono odpowiadać z wolnej stopy. Śledztwo przeprowadzili stronnicy radziwiłłowscy Jerzy Abramowicz i Józef Prószyński, którzy nie dopuścili do zeznawania świadków przeciwnej strony, uznając ich za uczestników zajścia. Tym samym wyrok był skrajnie stronniczy. Rozpoczęto poszukiwania ukrywającego się u jezuitów Frąckiewicza. Ksiądz Massalski rozważał konieczność przysłania konwoju, który umożliwiłby zbiegowi opuszczenie Wilna ${ }^{19}$.

Niesprawiedliwość, która - wedle wołczyńskiego stanowiska - spotkała stronników kanclerza, rychło stała się dowodem na nadzwyczajne bezprawie mające miejsce pod radziwiłłowską laską. Wykorzystując tumult, Michał Czartoryski wraz $\mathrm{z}$ klientelą rozpoczęli stosowną akcję propagandową.

W październiku 1755 r. Jan Rzyszczewski, sekretarz rosyjskiego poselstwa w Warszawie, donosił, że nad Wisłę doszedł go list podkanclerzego litewskiego Michała Antoniego Sapiehy o dramatycznych wypadkach wileńskich. Wywołało to jakoby ogromne poruszenie. W tych warunkach, wedle sekretarza, Czartoryscy mieli oczekiwać rosyjskiej pomocy ${ }^{20}$. Do swojej relacji dyplomata

${ }^{18}$ M.K. Radziwiłł do K.S. Radziwiłła, Nieśwież, 9 IX 1755, AR IV 876, s. 1060.

19 „Trybunał Skarbowy zakończył się sprawą obwinionych o porąbanie pana Wołodkowicza. Obwarowano liberum aditum et reditum panu Hołyńskiemu i panu Hurce, a nieboraka Frąckiewicza lepiej przygwożdżono, dawny dekret we wszystkim aprobując. Naznaczona inkwizycja do pałacu Flemmingowskiego, mająca się ekspediować przez pana Abramowicza podwojewodziego i Prószyńskiego deputata, obydwóch przychylnych Wołodkowiczowi, pierwszy koligat i największy jego protektor, drugi przyjaciel i kolega. Jakoż podczas inkwizycyi, która się wczoraj odprawiła, znać to było, bo tak rzeczy ułożono, żeby pan Wołodkowicz niewinnym koniecznie, a pan Frąckiewicz kryminalistą został, którego świadków pryncypalnych pro complicibus uznano i po tym im podawano pozwy. Z kolei dostał się i memu staroście orszańskiemu tenże prezent, chociaż on pod tę porę, kiedy się transakcja stała, znajdował w kompanii z panami Abramowiczami, czego się oni zaprzeć nie mogą. Ale że Frąckiewicza pewnemi świadectwami swojemi ratował, to go tym sposobem incapaces id do świadczenia uczynili. Całą machinę zwalili na kark Frąckiewicza, pod którą nie wiem, jak się ostoi, bo już po wszystkich traktach Tatarów i żołnierzy rozstawiono, żeby go złapać i tu czatują jak wilcy na niewinnego baranka. Do klasztoru nawet gdzie rozumiał, że i oddech swój utaił, słyszę, wkradł się jeden sługus Wołodkowicza i wszedł do jego celi, ale przecież księża jezuici, przed oczyma których nic się utaić nie może, postrzegli i pana sługusa wypchnęli. To pewna, że nieborak Frąckiewicz zostaje w wielkim niebezpieczeństwie, jeżeli nie życia, przynajmniej honoru. Godziłoby się mu przysłać konwój, inaczej zaś stąd nie wyjedzie”, I. Massalski do J. Massalskiego, Wilno, 14 IX 1755, B. Wróblewskich, F 139, d. 2712, k. 82-83 (dokładny odpis tego źródła zawdzięczam uprzejmości dr. Andrzeja Majewskiego, któremu składam uniżone podziękowania). Por. А. Мацук, Баращьба..., s. 396-397.

${ }^{20} \mathrm{~J}$. Rzyszczewski do Elżbiety I, Warszawa, 9/20 X 1755 (relacja nr 56, otrzymana 23 X/3 XI), APZIR, f. 79/1, d. 1755/7, k. 362-362v; tłumaczenie tegoż na rosyjski, ibidem, k. 364v-365v. 
załączył wspomniany „familijny” diariusz zajść, który zapewne również otrzymał od Sapiehy ${ }^{21}$.

Odpowiednie depesze zostały skierowane także do Drezna, a w Wołczynie oczekiwano informacji, jakie wrażenie wiadomości z Wilna wywołają na dworze królewskim. Michał Czartoryski pisał do zięcia, mając zapewne na myśli wspomniany wyżej tekst „familijnego" diariusza: „Na relacją o historii wil[eńskiej] jeszcze nie mam responsu od grafa Brühla. Ksiądz podkanclerzy [Michał Wodzicki przybył z Polski do Drezna 26 IX - TSz] odpisał vituperando, co się działo i że odzywał się z Drezna do Hubertsburgu [król opuścił stolicę Saksonii 1 X - TSz], radząc podpis listu żelaznego dla pana Frąckiewicza. Taki respons pana kanclerza w. k., że trzy dni myślał co z tym czynić i jeszcze nie wymyślił, a plurimae sobie rezerwuje do powiadania ad coram"22. Tydzień później mógł książę kanclerz donieść z satysfakcją: „Od grafa Brühla takowy odebrałem respons. Dziękuje mnie exagerative, że mu posłałem opisanie stałej w Wilnie eweniencyi, że ją prezentował królowi Jego Mości i lubo ta relacja differt od innych, jednakże JKMość w dowód swojej dla mnie benewolencyi podpisał list żelazny dla p. Frąckiewicza. Ten instrument posyłam p. Kłokockiemu w przyłączonej ekspedicyi, którą przeczytawszy i przypieczętowawszy racz WMWMPan odesłać do Mińska przez umyślnego z suplementem zdań i dispozycyi swoich w tej materyi"23.

Michał Kazimierz Radziwiłł otrzymał wiadomość o wypadkach wileńskich w ciągu kilku dni podczas pobytu w Koreliczach, gdzie zjechał się z synem, marszałkiem trybunalskim. Pierwszą reakcją hetmana była prośba skierowana do Abramowiczów i pisarza kadencji ruskiej Józefa Kaszyca, aby starali się skłonić Wołodkowicza do zgody z zamieszanymi w sprawę deputatami, przede wszystkim z Kazimierzem Hołyńskim, „nieodstępnej przyjaźni swojej ku nam stabiliter oświadczającym dowody". Gdyby to się nie udało, hetman planował zaproszenie zwaśnionych do Nieświeża na św. Michał, aby osobiście nalegać na pojednanie. Jednak „z deputatami tylko zgodzić się potrzeba”, pouczał swoich „partyzantów” wódz litewski, przewidując kontynuowanie procesu przeciwko pozostałym uczestnikom zajścia ${ }^{24}$. Radziwiłłowie liczyli zatem, że tumult nie skomplikuje prac zdominowanego przez nich trybunału. Odpowiednią relację zajść wysłał także Radziwiłł Janowi Klemensowi Branickiemu ${ }^{25}$, a w przypadku Mniszcha zapowiadał, że wiarygodnym źródłem informacji w sprawie będzie jego drezdeński agent ${ }^{26}$.

\footnotetext{
${ }^{21}$ Ekstrakt diariusza wileńskiego 29 VIII - 2 IX 1755 (zał. do rel. J. Rzyszczewskiego nr 56/1755), ibidem, k. 367-370v; tłumaczenie tegoż na rosyjski, ibidem, k. 371-391v.

${ }^{22}$ M. Czartoryski do M.A. Sapiehy, [Wołczyn], 29 X 1755, B. Narodowa, rkps 3285/II, k. 40.

${ }^{23}$ Idem ad idem, Wołczyn, 6 XI 1755, ibidem, k. 43.

${ }^{24}$ M.K. Radziwiłł do J. Abramowicza i J. Kaszyca, Korelicze, 5 IX 1755, AR IV 876, s. 1050-1051, 1051-1052.

${ }^{25}$ M.K. Radziwiłł do J.K. Branickiego, Mir, 7 IX 1755, ibidem, s. 1055-1056.

${ }^{26}$ M.K. Radziwiłł do J.A. Mniszcha, Mir, 7 IX 1755, ibidem, s. 1056-1057.
} 
Rzeczywiście hetman wielki litewski równocześnie wysłał do Drezna Andrzejowi Protasowiczowi nieświeską relację z wydarzeń wileńskich, nakazując, aby rozpoznawał i zbijał propagandę przeciwników. Protasowicz miał przedstawiać Mniszchowi nieczystą grę Wołczyna, wykorzystując w szczególności tumult, „gdy JMPana Wołodkowicza, człeka tak zacnego, trzeźwiuteńkiego, adherenci familii wiadomej sprowadziwszy zdradliwie do pałacu JMPana podskarbiego, in charactere deputacyi będącego (non memorata praxis) horrendissime zrąbali, nie inne to było studium onych, tylko in deffectu innych sposobów, niegodziwie forti manu moc swoją okazując, zhańbić trybunał, gloriose et plausibiliter pod imienia mego dyrekcją sądzący się" ${ }^{27}$. W odpowiedzi agent donosił swemu panu, że przekazał Jerzemu Augustowi Mniszchowi i Henrykowi Brühlowi stosowne informacje o wydarzeniach w Wilnie, przekonując ich, że była to prowokacja „familii” zmierzająca do kompromitacji trybunału. Marszałek nadworny koronny początkowo bagatelizował sprawę, sugerując, że osądzenie sprawców doprowadzi do zamknięcia problemu. Zadbał także Protasowicz o opinię publiczną: „Relacją zaś sprawiedliwą ostatniej akcyi w Wilnie w porąbaniu jp. Wołodkowicza, sędziego trybunału głównego WXLitt., który tu się i sam odezwał, takem rozgłosił i opowiedział, że i strony przeciwnej relacje miejsca nie miały do pozornej z tego justyfikacyi"28.

Wedle kolejnej relacji Protasowicza Michał Wodzicki przywiózł z Rzeczypospolitej nową wersję wydarzeń wileńskich, wyrażając oburzenie z powodu zajść i postulując, „aby ekscessanci zgadzającą się z prawem i sprawiedliwością swoją odnieśli karę". Ksiądz podkanclerzy chwalił jakoby postawę marszałka Radziwiłła, „że tak przykładnie i chwalebnie administrując sprawiedliwość, pierwszą trybunału tegoż zakończył kadencją"29. Widać zatem, że Wodzicki chciał ukryć przed Nieświeżem swoją profamilijną działalność w sprawie Frąckiewicza.

Wszelako dla Protasowicza i Mniszcha zły prognostyk stanowiła wiadomość z Wilna, że trybunał skarbowy dopuścił winowajców poranienia Wołodkowicza do odpowiadania $\mathrm{z}$ wolnej stopy (liberum aditum et reditum). Agent uznał, że decyzja sądu mogła utrudnić surowe osądzenie sprawców w Mińsku. Bulwersowała także postawa Abramowiczów, którzy nie wykazali należytego zaangażowania $\mathrm{w}$ sprawę ${ }^{30}$. W odpowiedzi hetman poinstruował agenta, że wspomniana decyzja podyktowana była względami taktycznymi na prośbę samego Wołodkowicza i służyła przede wszystkim osądzeniu Frąckiewicza, „motora albo raczej herszta tak szpetnej akcyi”. Radziwiłł usprawiedliwiał także Abramowiczów ${ }^{31}$.

\footnotetext{
${ }^{27}$ M.K. Radziwiłł do A. Protasowicza, Mir, 7 IX 1755, AR IV 876, s. 1053-1054.

${ }^{28}$ A. Protasowicz do M.K. Radziwiłła, Drezno, 24 IX 1755, AR, dz. V, nr 12416 [dalej: AR V 12416] / V, s. 200-204.

29 A. Protasowicz do M.K. Radziwiłła, Drezno, 1 X 1755, AR V 12416/V, s. 206.

${ }^{30}$ A. Protasowicz do M.K. Radziwiłła, Drezno, 8 X 1755, AR V 12416/V, s. 214-215.

${ }^{31}$ M.K. Radziwiłł do A. Protasowicza, Nieśwież, 19 X 1755, AR IV 876, s. 1105-1106. Niebawem jednak hetman zmienił zdanie: „Ma Pan pisarz mój obszernie wyrazić nieutulony żal mój
} 
21 października marszałek nadworny poinformował agenta radziwiłłowskiego, że Wodzicki wnosił o podpisanie listu żelaznego dla Frąckiewicza. August III, uczyniwszy to, oddał dokument na ręce marszałka nadwornego, aby ten odesłał go księdzu podkanclerzemu. Tym samym prawdziwa rola Wodzickiego w sprawie Frąckiewicza została przed Radziwiłłami zdemaskowana. Protasowicz zareagował manifestem złożonym na ręce Brühla oraz ustnymi enuncjacjami, upraszając, aby list żelazny nie został odesłany. Wskazywał na groźbę podważenia powagi trybunału i hetmana wielkiego litewskiego, „ale mi JO JPan graf pierwszy minister odpowiedział, że jest wolno JKrMości listy żelazne wydawać dla największych ekscesjonatów, a JPana Frąckiewicz nie zranił, owszem, powiada, z przyłączonych od drugiej strony informacyi niewinnym się pokazuje, jednakowoż wolno, powiada, będzie trybunałowi sądzić tę sprawę i rozeznać culpabiles". Protasowicz wskazywał także na fakt, że wobec niedawnej śmierci brata pierwszego ministra (16 X 1755 r. zmarł w Lipsku Karol Brühl, koniuszy saski), „podpisanie listu żelaznego zdało się być uczynkiem chrześcijańskim, gdy idzie o życie JPana Frąckiewicza i \{Mniszech\} nie mógł w to interesować mocno, taż sama racja chrześcijańska była mu pro obstaculo"32. List żelazny został odesłany Wodzickiemu niebawem, a agent hetmański poprzestał na nadziei, że nie przeszkodzi to w sprawiedliwym osądzeniu winowajców ${ }^{33}$.

W odpowiedzi na instrukcję Radziwiłła (z 19 X) Protasowicz wyjaśnił, że „nauczyła mnie dostatecznie”, iż podważanie przywiązania Abramowiczów było bezzasadne, a winowajcy odpowiadali $\mathrm{z}$ wolnej stopy na wniosek samego Wołodkowicza. Taką wersję wydarzeń Protasowicz przekazał Mniszchowi. „Nie omieszkałem o tym wszystkim zupełnej \{Mniszchowi\} uczynić remonstracyi, niemniej i obojętność \{JPana pisarza ziemskiego wileńskiego\}, że jej samże interes jego, jako zasiadającego w pośrodku złych i dobrych każdego roku \{deputatów\}, wyciąga po nim, jednakże mówił mi \{Mniszech\} jeżeli \{Wasza Książęca Mość\} pewien jesteś przyjaźni jego ku sobie statecznej, upewniałem, że się na niego JOWasza Książęca Mość Dobrodziej nie zawiedziesz"34.

Jednak niebawem sam Radziwiłł wyraził złość z powodu ugodowej postawy pokrzywdzonego: „P[an] Wołodkowicz, deputat miński porąbany, przez skąpstwo

Ichmościom Panom Abramowiczom, że za moją przyjaźń mizernie mnie oddają [...] pokazali Ichmoście dokumentalnie, że są moi nieprzyjaciele”, wśród zarzutów było skłonienie Wołodkowicza do ugodowej pozycji „tak, że dwór się dziwuje”. Instrukcja M.K. Radziwiłła dla Korsaka pisarza wojskowego, rezydenta przy K.S. Radziwille, Nieśwież, 6 XI 1755, ibidem, s. 1136.

32 A. Protasowicz do M.K. Radziwiłła, Hubertsburg, 21 X 1755, AR V 12416/V, s. 221-222. Nawiasem \{\} zaznaczam fragmenty samodzielnie przeze mnie odszyfrowane (Protasowicz posługiwał się bardzo prymitywnym szyfrem).

33 A. Protasowicz do M.K. Radziwiłła, Hubertsburg, 28 X 1755 (depesza rozproszona, cz. V, s. 223226, cz. VI, s. 7, 77-79), AR V 12416/V, VI, s. 224, 77.

${ }^{34}$ A. Protasowicz do M.K. Radziwiłła, Hubertsburg, 4 XI 1755, AR V 12416/VI, s. 8, 12. Agent nie wiedział, że stanowisko w sprawie Abramowiczów było już nieaktualne (zob. wyżej). 
godzi się o porąbanie. Już tedy będziem wiedzieli taksę członków jego. Jebał go pies"35. Gdy Protasowicz zameldował o tym Mniszchowi, marszałek nadworny wyraził dezaprobatę $e^{36}$. Miesiąc później agent donosił, że wprawdzie nie dysponował pewnymi informacjami o kompromisie w sprawie Wołodkowicza, podkreślał jednak „co gdyby do skutku przyszło, nie inaczej, tylko by mu to inhonestum za ugodą accipiens, ujęło sławy i honoru i ze wszech miar od każdego naganę" ${ }^{37}$.

Hetman nakazał jeszcze agentowi, aby przekonywał Mniszcha w sprawie listu żelaznego dla Frąckiewicza, „że familia wiadoma choć tą bagatelą, wielką, o zachowaniu i kredycie swoim u Pana, uczyni impresją." Mogło to utrudnić realizację radziwiłłowskich planów odnośnie przyszłego trybunału. Dał wyraz także swojemu rozgoryczeniu postawą Wodzickiego w sprawie immunitetu dla podstarościego pińskiego ${ }^{38}$. Marszałek nadworny koronny wymigał się, powołując się na wolę monarchy ${ }^{39}$.

Równolegle do podejmowanej akcji niedopuszczenia do wydania Frąckiewiczowi listu żelaznego, Protasowicz zamierzał użyć podstępu. 21 października Jerzy August Mniszech poinformował go, że do Hubertsburga za pośrednictwem Wodzickiego przyszedł od Michała Czartoryskiego diariusz wydarzeń wileńskich wraz z komentarzem ${ }^{40}$. Agent nieświeski donosił, że podkanclerzy koronny, mimo sojuszu z Radziwiłłami, w tej konkretnej sprawie chciał się zasłużyć Wołczynowi. W efekcie przysłał wspomniane teksty do gabinetu królewskiego z pominięciem Mniszcha, „przecież i w gabinecie potrafić tego nie mogą, aby się to JMPanu marszałkowi nadwornemu nie doniosło, owszem do rąk jego tu to wszystko, chociaż była rzecz zrobiona, oddano i gdyby tu JP[ana] marszałka nie było i jam tu [się] nie zjechał, chociaż tu prawie sowicie wszystko kosztuje, kiedy od jednej izdebki na wiosce, w której cztery kroki wzdłuż, a trzy wszerz, na miesiąc pięć talarów płacę, tedy by familia, jak z dawna tu czynić przyzwyczajona, tak sromotną akcją $\mathrm{w}$ trybunale zrobiwszy, tu u dworu za chwalebną udała, a wszystką winę na stronę sobie przeciwną zwaliła i teraz jeszcze w tej sytuacyi jak jest złośliwa uczyniła, ale się jej

${ }^{35}$ M.K. Radziwiłł do A. Protasowicza, Nieśwież, 26 X 1755, AR IV 876, s. 1121. Zapewne obawy o lojalność Wołodkowicza skłoniły początkowo hetmana, aby nie nalegać więcej na jego pojednanie z K. Hołyńskim, M.K. Radziwiłł od S. Zbińskiego, Nieśwież, 22 X 1755, ibidem, s. 1113-1114. Hetman obawiał się o jedność obozu radziwiłłowskiego: „gdyby teraz pewnie po zaszłej ugodzie JPana Wołodkowicza dwóch deputatów, jako to on sam i Hołyński, oderwie się, eksplikować to WMWMPan będziesz synowi memu, ale kartkę po przeczytaniu spalisz", M.K. Radziwiłł do ks. Woronicza SJ, Nieśwież, 27 X 1755, ibidem, s. 1123-1124. Przed samym Wołodkowiczem hetman ukrywał swoją złość, a następnie wrócił do misji pojednania go z K. Hołyńskim (na wniosek tego ostatniego), M.K. Radziwiłł do J. Wołodkowicza, Nieśwież, 27 X, 4 XI 1755, ibidem, s. 1125-1126, 1132-1133.

${ }^{36}$ A. Protasowicz do M.K. Radziwiłła, Hubertsburg, 11 XI 1755, AR V 12416/VI, s. 14.

37 A. Protasowicz do M.K. Radziwiłła, Drezno, 10 XII 1755, AR V 12416/VI, s. 45.

${ }^{38}$ M.K. Radziwiłł do A. Protasowicza, Nieśwież, 2 i 8 XI, Łachwa, 16 XI 1755, AR IV 876, s. 1131, $1140,1150$.

${ }^{39}$ A. Protasowicz do M.K. Radziwiłła, Hubertsburg, 18 XI 1755, AR V 12416/VI, s. 20, 23.

${ }^{40}$ A. Protasowicz do M.K. Radziwiłł, Hubertsburg, 21 X 1755, AR V 12416/V, s. 222. 
nie nadało i nie nada"41. Mniszech przekazał Protasowiczowi tekst diariusza, aby ten mógł sporządzić regestr, ten jednak sporządził odpis całości. Agent nieświeski rozpoznał znany sobie charakter ręki osoby z kancelarii kanclerza litewskiego, sam styl argumentacji „filozoficznemi argumentami napełniony” przypisywał pisarzowi Józefowi Sosnowskiemu. Przekonywał przy tym Brühla, że przekazana wcześniej przez hetmana relacja była rzetelna, a to, co przysłano z Wołczyna, było kłamstwem. W odpowiedzi pierwszy minister przyznał, że król znał tylko „familijną” wersję wydarzeń „i uznał z tego doniesienia, że JMPan Frąckiewicz pokazuje się być niewinnym temu" ${ }^{2}$. Protasowicz stwierdził zatem, że wprawdzie sąd osądzi sprawę, jednak tekst diariusza okazać się mógł bardzo szkodliwy, bowiem oczernić mógł skutecznie Karola Stanisława Radziwiłła i kierowany przezeń trybunał. Podważanie treści zawartych w diariuszu, wedle Protasowicza, na niewiele by się zdało, a zostawić bez odpowiedzi byłoby jeszcze gorzej. Przyszedł natomiast agentowi do głowy podstęp: „Ten jest tedy najskuteczniejszy i najchwalebniejszy do zabielenia mocnego środek i sposób, abyś WKsMość kazawszy sekretnie ten skrypt cudzą i nieznajomą ręką przepisać, nie wydając się żem ja, mając sobie komunikowany od JP[ana] marszałka nadwornego, przysłał WKsMości, ale udał, że się zjawił in publico ten paszkwil i z województwa brzeskiego dostał się księciu jegomości miecznikowi, posłał tenże skrypt do trybunału, aby przez trybunał judicaretur, przez kata był spalony on. Chwała Bogu, że jest tytuł na nim bez autora na nim podpisanego, więc jako famosus libellus temu rygorowi i sprawiedliwości podlegać powinien, to się łatwo circa pluralitatem stać może, ba i przeciwni deputaci temu opponere nie mogą, bo by się przez tą samą pokazali być complices"33. Ze swojego planu Protasowicz zwierzył się sekretarzowi Mniszcha Tarnawskiemu. Ten zaakceptował pomysł, jednak do marszałka nadwornego wolał się agent hetmański nie zwracać o radę w obawie o przeciek. Był natomiast przekonany, że jeżeli cała impreza zakończyłaby się pomyślnie, dwór byłby usatysfakcjonowany, nawet gdyby nie znał prawdziwych mechanizmów spisku. Sprawa zatem, przekonywał Protasowicz swojego patrona, wymagała najgłębszego sekretu. „Dopiecze to mocno księcia kanclerza, pozna dowodniej dwór, jak są nierzetelne od ministra dworowi doniesienia, a ta uczynność podobna będzie przykładowi niedawno w trybunale koronnym praktykowanemu, a wszystkich przyjaciół utwierdzi w mocniejszych $\mathrm{ku}$ WKsMości sentymentach" ${ }^{44}$.

\footnotetext{
${ }^{41}$ A. Protasowicz do M.K. Radziwiłła, Hubertsburg, 28 X 1755, AR V 12416/V, VI, s. 224-225, 77.

42 Ibidem, s. 225-226, 77-78. Protasowicz wyprzedził instrukcję hetmańską, która nieco później nakazywała zdobycie tekstu familijnego diariusza, M.K. Radziwiłł do A. Protasowicza, Nieśwież, 8 XI 1755, AR IV 876, s. 1140.

${ }^{43}$ A. Protasowicz do M.K. Radziwiłła, Hubertsburg, 28 X 1755, AR V 12416/V, VI, s. 226, 78.

${ }^{44} \mathrm{Ibidem}$, s. 226, 78-79; Protasowicz, pisząc o praktykach trybunału koronnego, miał na myśli spalenie broszury: [T. Dłuski], Odpowiedz na pytanie, ieżeliby na Dobra Ostrogskie administracya uproszona bydź mogła, [Warszawa 1754, druk pijarów]; K. Estreicher, Bibliografia polska, t. 15,
} 
Długo jednak agent nie utrzymał sekretu. Już kilka dni później wdrożył Mniszcha w swój plan. „Niepodobna wyrazić jak był z tego kontent JPan marszałek i sam na potym mocno życzył tego, aby się to w skutku stało, mówiąc, że byłby to najdoskonalszy sposób przez to zabieżeć temu tu fałszywemu o trybunale doniesieniu, chociaż, powiada, nie omieszkałem ja tu moich w tym remonstracyi, ale to nie jest tak skuteczne, jak by był mógł przez spalenie tego skryptu w trybunale, byle by tylko mnie, powiada, że wiem o tym, nie wydano, a jak się rzecz stanie, będzie zapewne od księcia jegomości kanclerza o to tu rekwizycja, ale ja, powiada, powiem tu, że ja o tym nie wiem, przypisze książę jegomość kanclerz to wszystko nieostrożności księdza podkanclerzego koronnego, któremu te doniesienie swoje powierzał, a interes, powiada, nasz dobrze by się udał"45.

Gdy do Protasowicza dotarły od Michała Kazimierza Radziwiłła wspomniane wyżej informacje, że Wołodkowicz był gotów do ugody, agent hetmański zaczął się obawiać, że „familia” wykorzystać to mogła dla uwiarygodnienia swojej wersji wydarzeń wileńskich. „Więc, per omnia, - dowodził agent - desideratum, aby ten posłany skrypt był za dekretem trybunału spalony, czego i sam JPan marszałek życzył, a to pomieszałoby z gruntu wszystkie przeciwne ułożenia, a JMPan Wołodkowicz, chociaż by się zgodził, to trybunał swojej obwinionym nie powinien darować lezyi, a byłoby desiderabile, gdyby trybunał JMPanu Wołodkowiczowi, jako także inwolwowanemu za zgodę jaką łatkę przypiął"

Protasowicz obawiał się, że depesza z treścią „familijnego” skryptu nie dotrze do Nieświeża przed wyjazdem hetmana Radziwiłła do Dubna. Błagał zatem mocodawcę, aby nawet $\mathrm{z}$ Wołynia nie zaniedbał wysłać odpowiednich instrukcji i doprowadzić do spalenia skryptu w Mińsku. Nieobecność Radziwiłła na Litwie była, zdaniem agenta, wręcz okolicznością korzystną. Zapewne chodziło o zafałszowanie tą drogą mechanizmu intrygi. Gdyby hetman nie wyraził woli przeprowadzenia sprawy, ,ja bym to partykularnie dla siebie za największe w całym życiu moim poczytał nieszczęście" ${ }^{37}$.

Nie mogąc się doczekać na odpowiedź patrona, Protasowicz informował, że zaniepokoiła go wiadomość uzyskana a latere, jakoby na Litwie uczyniono manifest przeciwko działalności bieżącego trybunału, podobny do tego, co „w refleksjach swoich książę kanclerz litewski ekskuzując akcją wileńską dworowi donosił i opisywał". Tekst miał zawierać tylko wyłożenie racji, bez dostatecznego wykładu prawa,

Kraków 1897 (reprint: Warszawa 1977), s. 250. Zob. też: A. Protasowicz do M.K. Radziwiłła, Warszawa, 12 XII 1754, AR V 12416/V, s. 10-11; P. Buchwald-Pelcowa, Cenzura w dawnej Polsce. Między prasą drukarską a stosem, Warszawa 1997, s. 50, 87-90; T. Szwaciński, Finał sejmu..., s. $174-175,178,188$.

${ }^{45}$ A. Protasowicz do M.K. Radziwiłła, Hubertsburg, 4 XI 1755, AR V 12416/VI, s. 8-9, 12.

46 A. Protasowicz do M.K. Radziwiłła, Hubertsburg, 11 XI 1755, AR V 12416/VI, s. 14-15, 18.

${ }^{47}$ A. Protasowicz do M.K. Radziwiłła, Hubertsburg, 18 i 25 XI 1755, AR V 12416/VI, s. 19-20, 23, $25,28$. 
na co Protasowicz nie omieszkał zwrócić uwagi Mniszchowi. Agent hetmański przypominał swój plan doprowadzenia do spalenia tekstu, jednak sugerował, „że gdyby quo casu takowy manifest był uczyniony, chociażby był na potym przez dekret trybunału eliminowany i spalony, zostałaby zawsze pamięć i impresja tego, kiedy rzecz jaka officiose czyni się"48.

Hetman Radziwiłł nie przystał jednak na intrygę: „Komunikowany mnie skrypt od WMWMPana rzecz prawdziwa, że pełen jest wierutnego fałszu i kłamstwa, które saepissime latranti ore na najwyższe targa się dostojności, laedere jednak tak nie zdoła, gdy by minueri miała ich powaga, bo nikczemność istoty onego, roztropną rozstrząsiona uwagą, ginie in sonitu vocis, przeto i trybunału litewskiego legibus sancita authoritas i sława syna mego, namiestniczą JKMci Pana N. Mił. władzę honeste et condigne piastującego, discrimini podpadać nie może, owszem te kłamliwe i nieuczciwe oczernienie nie wię[cej] od kogo rozważane, lecz odrzucone i zhańbione być powinno. Zaczym i propozycyi WMWMPana nie akceptując, a barziej fałszywych nie rozsiewając plotek, zniszczyć one u siebie consulte osądziłem" ${ }^{\prime \prime}$. Wyraził także hetman zdziwienie, że kanclerz rozpowszechnia teksty świadczące o niekompetencji w kwestiach prawnych oraz rozgoryczenie odnośnie roli przysłanej od siebie relacji: „zniszczyła ją pośledniejsza od strony przeciwnej przysłana, eksces fałszywą narratywą ukrywająca". Radziwiłł przyjął ponadto supozycję, że autorem familijnego diariusza był Sosnowski ${ }^{50}$. Protasowicz poinformował Mniszcha o stanowisku Nieświeża odnośnie kanclerskiego diariusza. Marszałek nadworny, prawdopodobnie starając się zamknąć i zbagatelizować temat, udzielił dość mętnej odpowiedzi, której agent hetmański nie mógł zrozumieć. Co zapewne było intencją przywódcy kamaryli51 .

Tymczasem w listopadzie 1755 r. Piotr Frąckiewicz przybył do Rygi. Być może znajdował się w większej grupie wysłanej przez Michała Czartoryskiego ${ }^{52} . \mathrm{Na}$ miejscu złożył na ręce tamtejszego wicegubernatora Fiodora Wojejkowa suplikę, w której przedstawił się jako reprezentant interesów Czartoryskich i Flemminga na trybunale litewskim, gdzie na skutek fałszywego oskarżenia został skazany na śmierć. Wymusiło to ucieczkę za granicę i prośbę o rosyjską protekcję $e^{53}$. Zapewne

48 A. Protasowicz do M.K. Radziwiłła, Drezno, 10 XII 1755, AR V 12416/VI, s. 42-45.

${ }^{49}$ M.K. Radziwiłł do A. Protasowicza, Łachwa, 16 XI 1755, AR IV 876, s. 1148-1149.

${ }^{50}$ Ibidem, s. 1149-1150.

${ }^{51}$ A. Protasowicz do M.K. Radziwiłła, Drezno, 17 XII 1755, AR V 12416/VI, s. 50-51, 57.

52 „Z Rygi miałem wiadomość, że moi posłańcy tam stanęli, że moje przez nich ekspedycje i zaraz poszły do Peterburga, a jak na nie będą responsa, przez tych moich ludzi będą przysłane", M. Czartoryski do M.A. Sapiehy, [Wołczyn], 14 XI 1755, B. Narodowa, rkps 3285/II, k. 44-44v; zob. też idem ad idem, [Wołczyn], 24 XI 1755, ibidem, k. 50v-51.

${ }^{53}$ Okoliczności te zostały opisane $\mathrm{w}$ późniejszych wytycznych dla rosyjskich dyplomatów: Elżbieta I do H. Grossa, Petersburg, 10/21 XI 1755 (reskrypt nr 56), APZIR, f. 79/1, d. 1755/3, k. 316; to samo: eadem do J. Rzyszczewskiego, Petersburg, 10/21 XI 1755 (ukaz nr 43), APZIR, f. $79 / 1$, d. $1755 / 5$, k. $158-158 v$. 
zanim dotarła odpowiedź z Petersburga, Frąckiewicz zaczął snuć plany kontruderzenia, do czego początkowo kanclerz Czartoryski odnosił się z rezerwą ${ }^{54}$. Jednak deklaracja Petersburga przyszła niebawem i mógł podstarości być nią usatysfakcjonowany. Zezwolono Frąckiewiczowi (jako wolnemu szlachcicowi) na swobodne zamieszkanie na terytorium wschodniego imperium. Znamienne, że owej zgody udzielono w pewnym stopniu „na kredyt”, bowiem równocześnie za wskazane uznano, aby dyplomaci rosyjscy w Dreźnie i Warszawie zweryfikowali rzetelność przedstawianej przez Frąckiewicza wersji wydarzeń ${ }^{55}$.

Gross otrzymał w Dreźnie stosowne polecenia 7 grudnia $1755^{56}$. Dyplomata odpowiadał, że sprawę znał z relacji podkanclerzego koronnego Michała Wodzickiego oraz agenta Czartoryskich Jacka Ogrodzkiego. Przedstawiona przez nich wersja wydarzeń potwierdzała treść supliki złożonej przez Frąckiewicza w Rydze ${ }^{57}$. Podkreślał niewinność podstarościego pińskiego, dowodząc, że radziwiłłowcy byli na niego szczególnie zawzięci, albowiem odrzucił łapówkę proponowaną w zamian za przejście w szeregi zwolenników Nieświeża ${ }^{58}$. Obie strony sporu, raportował Gross, przysłały do Drezna swoją wersję wydarzeń. Dwór mimo ówczesnej przychylności wobec Radziwiłłów, zdecydował się na wydanie Frąckiewiczowi listu żelaznego, co umożliwiło mu powrót do Rzeczypospolitej bez obawy o życie ${ }^{59}$.

${ }^{54}$ „Jest już w Rydze in salvo p. Frąckiewicz. Jeżeli by miał pozywać de laesione honoru, trzeba by na to sporządzić i przysłać jemu tenor pozwu, ale jeszcze nie widzę ad id fundamentu", M. Czartoryski do M.A. Sapiehy, [Wołczyn], 16 XI 1755, B. Narodowa, rkps 3285/II, k. 45-45v.

55 „И хотя мы ему Фронкевичу в ем его прошении отказать не отели но повелили по такому нашему [k. 316v] ғенералу майору Войейкову о нём Фронкевиче [przekreślenia oryginalne] объявить, что он яко вольный шляхтич для безопасности своей может свободу иметь в нашей империи, или где похочет безпрепятственно жить. Но понеже нам ведать потребно только ли сие произшествие учинено, как он Фронкевич объявляет. Того ради мы за потребно разсудили вам о том единственно для вашего известия и для того знать дать, дабы вы постарались в вашем месте через кого надлежит обо всём том под рукою наведаться, и что вами по тому делано будет, о том имеете к нам в непродолжительствие времён во известие доносить", Elżbieta I do H. Grossa, Petersburg, 10/21 XI 1755 (reskrypt nr 56), APZIR, f. 79/1, d. 1755/3, k. 316-316v; eadem do J. Rzyszczewskiego, Petersburg, 10/21 XI 1755 (ukaz nr 43), APZIR, f. 79/1, d. 1755/5, k. 158-158v.

${ }^{56}$ H. Gross do Elżbiety I, Drezno, 27 XI / 8 XII 1755 (rel. nr 116), APZIR, f. 79/1, d. 1755/4, k. 535.

${ }^{57}$ Gross weryfikował także nazwisko azylanta „которого подлинное имя Францкевич, а не Фронкевич", ibidem, k. 535-535v.

${ }^{58}$ Ibidem, k. 535v.

59 „С своей стороны маршалок трибунальской князь Радивил прислал сюда ко двору рапорт, которым явствует, что Францкевич нарочно членов зазвав их к драке напустил и что по тому, что яко убийца и возмутитель покоя приговорен к смерти.Однакож же на против того канцлер литовский двору доносит всё то, еже я честь имел выше сего описать, хотя двор от времени острогского спора гораздо склоннее фамилии Радивилов, однакож уважая нарушение формалитетов и скоропостижное пристрастное Францкевича осуждение, король соизволил по реченного канцлера представлению дать сему шляхтичу салвогардию или по польски называемое железное письмо в минувшем ноябре в Губертсбурге подписанное, в следствие которого Францкевичу конечно вольно опять в Польшу или Литву 
Równolegle z Grossem odpowiedział także Rzyszczewski. Sekretarz poselstwa powoływał się przy tym na październikowe pismo podkanclerzego Sapiehy ${ }^{60}$. Ponieważ w Petersburgu nie odnaleziono listu podkanclerzego, nakazano dyplomacie przysłanie jego kopii, co wskazuje, że jeszcze pod koniec roku czynniki petersburskie wykazywały zainteresowanie sprawą Frąckiewicza ${ }^{61}$.

Podczas kadencji mińskiej trybunału litewskiego (od $13 \mathrm{X}$ ), mimo zakończonego śledztwa, początkowo nie przywołano aktoratu Józefa Wołodkowicza. Wedle Matuszewicza sprawa była łatwa do wygrania przez obóz radziwiłłowski, bowiem trzej deputaci popierający „familię” (Zawisza, Daneyko, Hołyński), jako pozwani, nie mogli brać udziału w głosowaniu i zostaliby kondemnowani ${ }^{62}$. Musiało zatem dojść do chwilowego kompromisu, o którym wspominały przywołane wyżej źródła.

W miesiącach następnych sprawa Frąckiewicza oraz wrześniowego tumultu zeszła na dalszy plan. Od 29 listopada 1755 r. osią konfliktu zaczęło być bezprawne zwycięstwo Matuszewiczów w procesie przeciwko Michałowi Czartoryskiemu. Tym bardziej że wydarzeniom tym również towarzyszył tumult, którego ofiarami padli tym razem stronnicy Wołczyna ${ }^{63}$. Wedle pamiętnikarza obydwa zajścia zostały symbolicznie połączone: „Wtem Wołodkowicz, deputat piński [sic - TSz], przypomniawszy krzywdę swoją do Danejki, deputata nowogródzkiego, który był complex porąbania jego na traktamencie Frąckiewiczowskim w Wilnie, dał Danejce tak mocno w gębę, że ten jak snop padł o ziemię"64.

Frąckiewicz pod koniec 1755 r. był już w kraju. Według Marcina Matuszewicza, jadąc samotnie incognito, spotkał przypadkiem w Lejpunach brata pamiętnikarza, Józefa. Jako że był ścigany, błagał, aby go nie odstawiać do trybunału na pewną

для надлежащего своего оправдания возвратится, не опасаясь исполнения противного ему трибунального декрета", ibidem, k. 536.

${ }^{60}$ Relacja Rzyszczewskiego (nr 65, z 27 XI / 8 XII 1755) nie jest znana. Jej treść, numer i data wspomniana została w cedule: Kolegium Spraw Zagranicznych do J. Rzyszczewskiego, Petersburg, 16/27 XII 1755, APZIR, f. 79/1, d. 1755/5, k. 173. Na temat wybrakowania relacji Rzyszczewskiego z 1755 r. zob. T. Szwaciński, Protekcja rosyjska..., s. 49.

${ }^{61}$ Październikowego listu od M.A. Sapiehy poszukiwano przy relacji Rzyszczewskiego nr 56/1755. Ponieważ tekstu nie znaleziono, nakazano sekretarzowi poselstwa przysłanie jego kopii. Zob.: adnotacja na rel. Rzyszczewskiego nr 56/1755, APZIR, f. 79/1, d. 1755/7, k. 365; Kolegium Spraw Zagranicznych do J. Rzyszczewskiego, Petersburg, 16/27 XII 1755 (ceduła), APZIR, f. 79/1, d. $1755 / 5$, k. 173. Odpowiadając, Rzyszczewski zadeklarował, że oryginalny list M.A. Sapiehy o prześladowaniach Frąckiewicza, wspomniany przezeń w rel. nr 56/1755, załączył do rel. nr 54/1755. Zob.: J. Rzyszczewski do Elżbiety I, Warszawa, 8/19 I 1756 (rel. nr 4), APZIR, f. 79/1, d. 1756/8a/I, k. 85; tłumaczenie tegoż na rosyjski ibidem, k. 87v. Z moich ogólnych notatek dotyczących rel. Rzyszczewskiego nr 54/1755 i jej załączników nie wynika, aby znajdował się tam wspomniany list, jednak sprawę muszę pozostawić otwartą (APZIR, f. 79/1, d. 1755/7, k. 313-325).

${ }^{62}$ M. Matuszewicz, op. cit., t. 1, s. 578.

${ }^{63}$ „Z Mińska”, 4 XII 1755, AR V 12416/VI, s. 146-147; M. Matuszewicz, op. cit., t. 1, s. 575-599; А. Мацук, Баращъба..., s. 397-399, 414-415.

${ }^{64}$ M. Matuszewicz, op. cit., t. 1, s. 598. 
śmierć, na co pułkownik, jakoby niezainteresowany sprawą, ochoczo przystał ${ }^{65}$. Trudno dać wiarę tej wersji wydarzeń, zważywszy na wydany podstarościemu pińskiemu list żelazny.

W początkach 1756 r. Michał Czartoryski wysłał do Jana Rzyszczewskiego list z prośbą o przekazanie jego treści do Petersburga. Sprawa Frąckiewicza została tu przedstawiona jako ważny element bezprawia dziejącego się w radziwiłłowskim trybunale. „Familia”, wyjaśniał kanclerz litewski, wysłała na trybunał Frąckiewicza, aby reprezentował tam jej interesy, co wywołało ogromną zawziętość na niego ze strony przeciwnej. W efekcie, wedle donosu księcia kanclerza, „[w] stancyi JMPana Frąckiewicza z wizytą przyjacielską zeszło się kilkanaście zacnych osób, między niemi był jeden $\mathrm{z}$ sędziów trybunalskich, do tej kompanii przyszedł drugi sędzia pijany, powadzili się i porąbali ci koledzy. JMPan Frąckiewicz jako w swojej stancyi i szabli nie miał przy buku, rozwadzał ile mógł, bijących się. Tak niewinną osobę zaraz łapać i wiązać kazano, ledwo się mógł salwować do klasztoru. Lubo kadencja trybunału w Wilnie już była in vigilia skończona", mimo to z naruszeniem prawa zebrali się sędziowie i skazali Frąckiewicza, który w obawie o życie musiał uchodzić za granicę ${ }^{66}$. Rezydent rosyjski w Warszawie załączył wspomniany list do relacji, podkreślając, że ukazane przez Czartoryskiego okoliczności zasługiwały na szczególną uwagę ${ }^{67}$.

Na przestrzeni pełnego napięć na Litwie roku 1756 sprawa tumultu wileńskiego wracała już tylko echem. W marcu Protasowicz donosił z Drezna, że podczas konferencji, którą odbył z Brühlem, omawiali otrzymane od Wołodkowicza informacje, wedle których starosta krasowski uzyskał dekret trybunału odsyłający wojskowych uczestników zajścia do sądów hetmańskich. Obydwaj uczestnicy narady zgodzili się, że takie osądzenie winowajców byłoby korzystne ${ }^{68}$. Także marszałek wielki litewski, stronnik Nieświeża, Ignacy Ogiński radził, aby sprawę poranienia Wołodkowicza wykorzystać w ramach sądów wojskowych. Pełniący służbę wojskową uczestnicy tumultu byli jeszcze w połowie $1756 \mathrm{r}$. sądzeni przez sądy hetmańskie, nie miało to jednak dla nich poważniejszych konsekwencji ${ }^{69}$. Mimo to w lipcu podczas rozmowy z Protasowiczem Brühl wyjawił, że „familia” przysyła mu skargi na hetmana Radziwiłła. Donoszono, że sprawy sądzone wcześniej $\mathrm{w}$ trybunale zostały przeniesione do sadów hetmańskich. Pierwszy minister saski

${ }^{65}$ Ibidem, s. 601-602.

${ }^{66}$ M. Czartoryski do J. Rzyszczewskiego, Wołczyn, 9 I 1756 (zał. A do rel. Rzyszczewskiego nr 2/1756), APZIR, f. 79/1, d. 1756/8a/I, s. 36-39; tłumaczenie tegoż na rosyjski, ibidem, s. 40-50. Por. T. Szwaciński, Władysław Konopczyński o szpiegu pruskim Lambercie. Pytania o orientacje zagraniczna Jerzego Augusta Mniszcha, w: Władysław Konopczyński jako badacz dziejów XVIII wieku, red. Z. Zielińska, W. Kriegseisen, Warszawa 2014, s. 103.

${ }^{67}$ J. Rzyszczewski do Elżbiety I, Warszawa, 8/19 I 1756 (rel. nr 2), APZIR, f. 79/1, d. 1756/8a/I, k. 31-32v; tłumaczenie tegoż na rosyjski, ibidem, k. 33-35v.

${ }^{68}$ A. Protasowicz do M.K. Radziwiłła, Drezno, 31 III 1756, AR V 12416/VII, s. 50, 53-54.

${ }^{69}$ А. Мацук, Барацьба..., s. 428, 430-432. 
pisał w tej sprawie do hetmana wielkiego litewskiego, chociaż „przydał oraz to, że zaniesione skargi niczym tu są i nic niewarte". Rezydent jednak sprawy nie bagatelizował, bowiem wystąpił do Mniszcha, „aby swoje w tym także JPanu grafowi Brühlowi przełożył remonstrancje, bo domyślam się, że to jest sprawa w akcyi porąbania JPana Wołodkowicza". Protasowicz podkreślał, że motywem akcji „familii” był zamach na prerogatywy hetmańskie $e^{70}$.

Mały drezdeński intrygant meldował jeszcze swojemu mocodawcy, że sprawa „familijnego" diariusza przyniosła mimo wszystko pewne korzyści: „KsJMość kanclerz lit. pisał tu do JMKs[iędza] podkanclerzego kor., utyskując na indyferencją dworu [w sprawach zbliżającej się reasumpcji - TSz], przy tym wyraził, pisząc swoją ręką, że miałby co więcej do doniesienia, ale, powiada, zamilczeć woli i nie nadgłaszać się onemu, aby się od niego dalej in publicum nie wyniknęło, jako powiada, że komunikowana onemu dawniej relacja o sprawie JP[an]a Frąckiewicza dostała się copiatim WKsMości, z czego ja partykularnie kontent jestem, że już ubliży KsJMość kanclerz swojej do JMKs[iędza] podkanclerzego kor. konfidencyi i przez to miałby trudność doniesienia się dworowi, chcąc niewinnie oczerniać kogo. JMKs[iądz] podkanclerzy kor. o takowej KsJMości kanclerza do siebie odezwie doniósł mi sam i pytał mię, jeżelibym ja tego skryptu WKsMości nie komunikował, ale ja fortiter negavi" ${ }^{\prime}$. Pozostaje jednak bardzo prawdopodobne, że była to nadinterpretacja (pewnie celowa) samego agenta lub Mniszcha, który, przypomnijmy, liczył, że sprawa diariusza obciąży relacje Michała Czartoryskiego z Michałem Wodzickim. Jednocześnie Protasowicz przypominał gwałt na Wołodkowiczu, gdy „familia” interweniowała w sprawie znieważenia deputata wołkowyskiego Stanisława Smogorzewskiego podczas listopadowego tumultu w Mińsku².

W okresie poprzedzającym nową reasumpcję drezdeński agent hetmański podpowiadał mocodawcy argumenty przeciwko „familii”, których użyć należało w korespondencji z Dreznem. Jednym z ich był fakt, że „familia”, po przegranej Czartoryskiego z Matuszewiczami, podburzała szlachtę do konfederacji. Województwo mścisławskie jakoby planowało uczynić związek z powodu kondemnaty oskarżonego o poranienie Wołodkowicza Hołyńskiego, który nie stawił się na rozprawę. „Toć już by ex praejudicato - radził hetmanowi pisać nad Łabę rezydent - każdy mocny mając sprawę w trybunale, a przegrawszy ją, szlachtę do takich inkonweniencyi animował, to by już i trybunału nie potrzeba było"73. Czy rzeczywiście szlachta mścisławska zamierzała wstawić się za osądzonym krajanem, przy obecnym stanie wiedzy nie sposób powiedzieć.

\footnotetext{
${ }^{70}$ A. Protasowicz do M.K. Radziwiłła, Drezno, 7 VII 1756, AR V 12416/VII, s. 148-149, 152.

${ }^{71}$ A. Protasowicz do M.K. Radziwiłła, Drezno, 14 IV 1756, AR V 12416/VII, s. 71-72, 76-77.

72 Ibidem, s. 73-74, 77-78.

${ }^{73}$ A. Protasowicz do M.K. Radziwiłła, Drezno, 28 IV 1756, ibidem, s. 82, 85-86. Por. А. Мацук, Барацьба..., s. 412.
} 
Frąckiewicz nie wziął udziału w kampanii sejmikowej „familii” przed reasumpcją $1756 \mathrm{r}^{74}$, reprezentował jednak cały czas księcia kanclerza w sprawie z Matuszewiczami, choć, wedle pamiętnikarza, okazał wobec patrona pewną nielojalność ${ }^{75}$. Na początku 1757 r. prowadzono kombinację jego konfliktu z Wołodkowiczem ${ }^{76}$. Do aktywnej działalności politycznej w obozie wołczyńskim powrócił w okresie bezkrólewia, gdy został posłem z Pińska na sejm konwokacyjny ${ }^{77}$.

Z kolei Józef Wołodkowicz wziął aktywny udział w obozie radziwiłłowskim w kampanii przed trybunałem 1756 r., zostając dyrektorem sejmiku gromnicznego w Mińsku ${ }^{78}$. Protasowicz wymienił go wśród ofiar represji sądowych pod laską Jerzego Flemminga ${ }^{79}$. W tym duchu jego casus przywoływany został także $\mathrm{w}$ radziwiłłowskim memoriale opisującym konflikty litewskie z latach $1755-1756^{80}$. 13 lutego 1760 r. jego rodzony brat Michał, będąc deputatem z Mińska, został rozstrzelany z wyroku trybunalskiego ${ }^{81}$. W 1763 r. Ignacy Massalski żądał usunięcia Wołodkowicza z grona stronników Nieświeża, uznając to za warunek porozumienia między Karolem Stanisławem Radziwiłłem a Massalskimi ${ }^{82}$.

Podsumowując, trzeba stwierdzić, że zaprezentowane powyżej fakty i zjawiska zasługują na uwagę $\mathrm{z}$ trzech podstawowych powodów.

Pierwszy to rodzące się w sposób naturalny pytanie, czy zjawisko poranienia deputata podczas prac trybunału było stałym elementem praktyki życia sądowego w Wielkim Księstwie Litewskim doby panowania Augusta III. Wydaje się,

${ }^{74}$ А. Мацук, Барацьба..., s. 399-429.

${ }^{75}$ M. Matuszewicz, op. cit., t. 1, s. 682, 691, 732.

${ }^{76}$ Ibidem, s. 779.

77 T. Szwaciński, Sejmiki poselskie przed konwokacja 1764 r., „Kwartalnik Historyczny” 2006, t. 113, nr 1, s. 42.

${ }^{78}$ Deputaci..., s. 250; А. Мацук, Барацьба..., s. 410.

79 A. Protasowicz do M.K. Radziwiłła, Drezno, 14 VII 1756, AR V 12416/VII, s. 156.

80 „9no Jp. Józefa Wołodkowicza, wojskowicza mińskiego charakterem funkcyi deputackiej w r [ok]u przeszłym zaszczyconego, nie uważając na publiczne bezpieczeństwo sądów trybunalskich i osób sędziowskich tylu prawami obwarowane, jp. Frąckiewicz plenipotent JOKscia JMści kanclerza w. WKsL, zgromadziwszy pierwej tumult, zdradliwie do siebie zaprosił, zaproszonego gromadą zrąbano, o co za intentowanym w trybunale prawa procesem, po wyprowadzonej inkwizycyi i po zupełnej konwikcyi za dekretem remisyjnym trybun[alskim], sprawa do sądów hetmańskich odesłana, w onych prozekwowana, a przez jp. Hołyńskiego, oficjalistę w służbie wojskowej zostającego, i jp. Hurkę towarzysza, nie zważając na dekreta hetmańskie w trybunale kontynuowana i jp. Wołodkowicz w sądach trybun[alskich] uzdawany na gardło i łapanie, ścięcie oraz przez mistrza.", Memoriał w sprawach litewskich z 1756 r., Paryż, Biblioteka Polska w Paryżu, rkps 27, nr 28, s. 209-224 (cyt. s. 223). Tekst ten dotyczy wielu sporów prawnych (w 9 punktach), dlatego opis nadany mu przez Czesława Chowańca jest mylący (Katalog Rękopisów Biblioteki Polskiej w Paryżu, t. 1, oprac. Cz. Chowaniec, Kraków 1939, s. 23). Dodajmy także, że spisany został w dwóch równoległych wersjach językowych polskiej i francuskiej.

${ }^{81}$ Deputaci..., s. 262; W. Kriegseisen, [rec.:] M. Czeppe, Kamaryla Pana z Dukli..., „Kwartalnik Historyczny" 1999, t. 106, nr 3, s. 103-104.

${ }^{82}$ M. Matuszewicz, op. cit., t. 2, s. 340-341. 
że odpowiedź jest przy obecnym stanie wiedzy z góry skazana na małą precyzyjność. Należy więc pozostawić to pytanie otwartym do czasu systematycznego przebadania praktyki prac trybunalskich w Wilnie, Mińsku i Nowogródku w ciągu całego wspomnianego wyżej okresu.

Drugi powód to protekcja rosyjska udzielona Frąckiewiczowi. Być może nigdy nie uda się odpowiedzieć na pytanie, czy ucieczka Frąckiewicza do Rygi była $\mathrm{z}$ góry przewidziana $\mathrm{w}$ strategii wołczyńskiej jako sposób na pobudzenie rosyjskiego zainteresowania bezprawiem $\mathrm{w}$ trybunale litewskim, czy też odwrotnie, sukces supliki Frąckiewicza skłonił Michała Czartoryskiego do uczynienia jego sprawy jednym $\mathrm{z}$ ważniejszych elementów argumentacji przedstawionej w liście do Rzyszczewskiego ze stycznia 1756 r. Jednak bez względu na szczegóły kształtowania się wołczyńskiej strategii podkreślmy, że przyniosła ona pozytywny rezultat. Rosja podjęła na dworze sasko-polskim interwencję na rzecz „familii” w sprawie reasumpcji trybunału w 1756 r. Petersburg wykorzystał przy tym (w odpowiednim reskrypcie do Heinricha Grossa) znaczną cześć argumentacji Michała Czartoryskiego ze wspomnianego listu. Sprawa tumultu wileńskiego nie została wspomniana explicite, tę rolę zarezerwowano dla wydarzeń z Mińska ${ }^{83}$.

Wreszcie, po trzecie, godny uwagi jest plan Protasowicza związany z przeprowadzeniem prowokacji polegającej na dystrybucji „familijnego” diariusza w Brzeskiem, a następnie jego publicznym spaleniem. Nawet jeżeli nie odważymy się na supozycję, że pomysłodawcą tego przedsięwzięcia był w rzeczywistości Mniszech, to entuzjastyczna reakcja marszałka nadwornego koronnego na projekt intrygi rzuca dodatkowe światło na metody działania przywódcy „kamaryli”" Zauważmy także (nie tylko przy okazji diariusza) dość wyraźny chaos i niekonsekwencję w działaniach stronnictwa radziwiłłowskiego, co wyraźnie odróżniało je od konkurentów.

Dodajmy jeszcze, że podstawowym celem powyższych rozważań było ukazanie politycznego aspektu tumultu wileńskiego. Nie mniej interesujące pole badawcze może stanowić traktowany tu pobocznie wątek formalno-prawny wraz $\mathrm{z}$ towarzyszącą mu polemiką stronnictw. Wydaje się jednak, że jego rzetelne i systematyczne odsłonięcie wymaga kwerendy litewskich akt trybunalskich znajdujących się w zasobie Archiwum Historycznego Państwa Litewskiego w Wilnie, niezbędna byłaby również w tym przypadku szczegółowa analiza wspomnianych wyżej „familijnego” diariusza i radziwiłłowskiej relacji (pod warunkiem, że zostanie odnaleziona).

${ }^{83}$ Elżbieta I do H. Grossa, Petersburg, 12/23 III 1756 (reskrypt nr 17), APZIR, f. 79/1, d. 1756/5, k. 53-72. Na temat reskryptu nr 17/1756 zob. też: T. Szwaciński, Rosja a Piotr i Jan Sapiehowie $w$ dobie kryzysu ostrogskiego (1754-1758), „Kwartalnik Historyczny” 2012, t. 119, nr 1, s. 54-55; idem, Władysław Konopczyński o szpiegu..., s. 103-104.

${ }^{84} \mathrm{Na}$ temat innego przykładu świadczącego o skłonności J.A. Mniszcha do intryg por. T. Szwaciński, Władysław Konopczyński o szpiegu..., s. 96-103. 


\section{Streszczenie}

Pod koniec sierpnia 1755 r. w czasie sesji trybunału w Wilnie doszło do krwawych zajść. Ich ofiarą padł Józef Wołodkowicz, deputat z Mińska. Głównym oskarżonym stał się pełnomocnik Michała Czartoryskiego, Piotr Frąckiewicz. Był to element zaostrzającej się wówczas walki stronnictw na Litwie. W obawie przed karą Frąckiewicz zbiegł do Rygi, gdzie wystąpił o protekcję rosyjską. Obie strony konfliktu oskarżały się wzajemnie o bezprawie i wysłały odpowiednie „diariusze” na dwór królewski do Drezna. W obozie Michała Kazimierza Radziwiłła pojawił się projekt osądzenia i publicznego spalenia „diariusza” przeciwników. Hetman odrzucił jednak ten projekt. Natomiast Michał Czartoryski przywołał sprawę Frąckiewicza, prosząc Rosję o pomoc przed reasumpcją trybunału litewskiego w $1756 \mathrm{r}$.

\section{A bloody incident in Wilno (1755) and its repercussions Summary}

At the end of August 1755 at the tribunal in Wilno (Vilna, Vilnius) there was a bloody incident. The victim was Józef Wołodkowicz, a judge from Minsk. The main accused was to become Michał Czartoryski’s agent, Piotr Frąckiewicz. It was a symptom of intensifying rivalry between the factions in Lithuania. Frąckiewicz sought Russian protection after he had fled to Riga. Both sides accused each other of lawlessness and sent the relevant 'diaries' to the royal court in Dresden. In the camp of Michał Kazimierz Radziwiłł there appeared a project of a scheme to adjudge and to burn publicly the 'diary' of the opponents. The hetman, however, rejected this project. On the other hand, Michał Czartoryski called upon Frąckiewicz's case, asking Russia for help before the resumption of the Lithuanian tribunal in 1756.

\section{Bibliografia}

\section{Źródła drukowane}

Matuszewicz M., Diariusz życia mego, wyd. B. Królikowski, koment. Z. Zielińska, Warszawa 1986.

\section{Opracowania}

Buchwald-Pelcowa P., Cenzura w dawnej Polsce. Między prasą drukarską a stosem, Warszawa 1997.

Czeppe M., Kamaryla Pana z Dukli. Kształtowanie się obozu politycznego Jerzego Augusta Mniszcha 1750-1763, Warszawa 1998.

Deputaci Trybunału Głównego Wielkiego Księstwa Litewskiego (1697-1794). Spis, oprac. A. Rachuba, P.P. Romaniuk, współpr. A. Macuk, J. Aniszczanko, Warszawa 2004.

Katalog Rękopisów Biblioteki Polskiej w Paryżu, t. 1, oprac. Cz. Chowaniec, Kraków 1939.

Konopczyński W., Polska w dobie wojny siedmioletniej, cz. 1: 1755-1758, Kraków-Warszawa 1909.

Kriegseisen W., [rec.:] M. Czeppe, Kamaryla Pana z Dukli..., „Kwartalnik Historyczny” 1999, t. 106, nr 3, s. 103-104.

Szwaciński T., Finał sejmu 1754 r. w relacjach rosyjskich i brytyjskich, „Biblioteka Epoki Nowożytnej” 2016, t. 4, s. 163-195.

Szwaciński T., Protekcja rosyjska udzielana przedstawicielom szlachty litewskiej u progu wojny siedmioletniej. Postawienie problemu, „Kwartalnik Historyczny” 2011, t. 118, nr 1, s. 47-83.

Szwaciński T., Rosja a Piotr i Jan Sapiehowie w dobie kryzysu ostrogskiego (1754-1758), „Kwartalnik Historyczny" 2012, t. 119, nr 1, s. 31-65. 
Szwaciński T., Sejmiki poselskie przed konwokacja 1764 r., „Kwartalnik Historyczny” 2006, t. 113, nr 1, s. 19-56.

Szwaciński T., Władysław Konopczyński o szpiegu pruskim Lambercie. Pytania o orientację zagraniczna Jerzego Augusta Mniszcha, w: Władysław Konopczyński jako badacz dziejów XVIII wieku, red. Z. Zielińska, W. Kriegseisen, Warszawa 2014, s. 93-106.

Zielińska Z., Pociej Ludwik, w: Polski Słownik Biograficzny, t. 27, Wrocław 1983, s. 47-49.

Мацук А., Барацьба магнацкіх груповак у ВКЛ (1717-1763 г2.), Мінск 2010.

Мацук А., Унутрыпалітычная сітуацыя у Вялікім Княстве Літоўскім у сярэдзіне XVIII cm. у сувязі з падзелам Астрожскай ардынацыі, „АRCНЕ-Пачатак” 2011, nr 6 (105), s. 115-141.

Tomasz Szwaciński - dr; absolwent Instytutu Historycznego Uniwersytetu Warszawskiego, pracownik naukowy Biblioteki Narodowej w Warszawie (Instytut Książki i Czytelnictwa). Jego zainteresowania badawcze obejmują stosunki polsko-rosyjskie w połowie XVIII w. oraz dzieje zbiorów polskich w Rosji. E-mail: t.szwacinski@wp.pl 